\title{
Research and the Social Agenda: The Tale of Two Rivers (Of Dead Rivers and the River of Life)
}

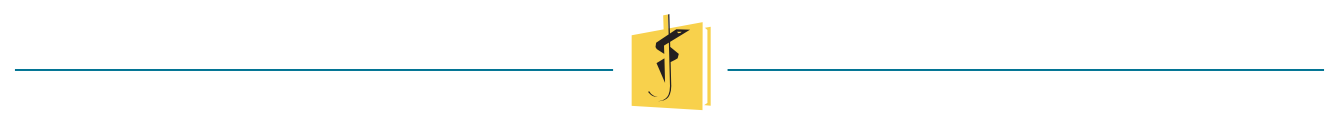

Maria Minerva P. Calimag, MD, MSc, PhD ${ }^{1,2,3}$

This oration was delivered by the author during the annual discurso de apertura at the formal opening of the academic year 2019-2020 at the University of Santo Tomas last August 1, 2019. The discurso started as a Dominican Catholic tradition on July 16, 1866 as an annual event.[1] The professor or dean assigned the preparation of this academic paper is appointed by the rector of the university a few months prior to the opening of each school year.[2]

\section{"Our lives begin to end the day we become silent about things that matter." \\ - Martin Luther King Jr [3]}

In my life-journey as a researcher, following my passion has allowed me to wander into new and uncharted territories, sometimes inadvertently. Unbridled by traditions, research has been for me a life-long journey of discovery-of who I am, of the world around me, and the meaning of life. Through research, I jolted some, rocked a few, gave voice to many and inspired many of my colleagues to follow my ways.

\footnotetext{
Maria Maria P. Calimag, MD, MSc, PhD

mpcalimag@ust.edu.ph

1 Professor, Faculty of Medicine and Surgery, University of Santo Tomas

2 Senior Associate Researcher, Research Center for Social Science and Education

3 Senior Associate Researcher, Research Center for the Health Sciences
}

When I received the news that I shall speak at today's discurso de apertura, I prayed and asked God to bless me with wisdom. Today, I intend to poke and stir all, so that by the ripples we create, we can make waves of positive change.

Home is where it all started! Our father Serafin V. Patawaran was a science teacher at the Letran High School and the UST High School, and our mother Concepcion Villanueva-Patawaran was a mathematics teacher at the UST Faculty of Pharmacy.

Our mother taught physics and geometry, among others, and she showed us how math ordered the patterns and rhythms of nature, as in the Fibonacci sequence or nature's code.

Our father taught earth science and biology. As a child, I remembered our father teaching us about nature, and that all living things are interconnected! He reminded us that we should respect the water cycle because water that goes up eventually comes back to us.

For $60+$ years, I have invested numerous resources in making these seeds of wisdom grow and bear good fruits.

From ancient times, nature has revealed an interconnected life force to humans, in the form of rhythms, patterns and cycles. But as man progressed, we have forgotten the life-giving forces of nature, and instead of protecting it, many have chosen to exploit it.

In 'Laudatosi,' Pope Francis' second encyclical subtitled "on care for our common home," the Pope deplores the environmental degradation and global 
warming brought about by consumerism and irresponsible development, and calls all people of the world to take "swift and unified global action." [4] It is the new appeal from Pope Francis addressed to "every person living on this planet" for an inclusive dialogue about how we are shaping the future of our planet. Pope Francis calls the Church and the world to acknowledge the urgency of our environmental challenges and to join him in embarking on a new path.

In his book "An Inconvenient Truth," the former US Vice President Al Gore, an advocate for the environment-essayed the planetary emergency of global warming and its disastrous consequences. [5]

The Philippines is prone to natural disasters, particularly typhoons, floods, landslides, volcanic eruptions, earthquakes, and tsunamis, lying as it does astride the typhoon belt, in the active volcanic region known as the "Pacific Ring of Fire." The Philippines, however, also suffers significant human-caused environmental degradation including loss of agricultural lands, deforestation, soil erosion, air and water pollution, improper disposal of solid and toxic wastes, loss of coral reefs, mismanagement and abuse of coastal resources. Human-driven and natural loss of trees-deforestation-affects wildlife, ecosystems, weather patterns and even the climate.[6]

As the climate changes, mosquito and tick vectors adapt to new environments, which lead to shifts in the spatial distribution, seasonality and incidence rates of disease-carrying mosquitoes and ticks as they move to different regions. The incidence of dengue fever, malaria, zika and chikungunya has increased throughout the years.

The 2015-2016 El Niño triggered disease outbreaks across the globe. Fluctuations in climate variables such as temperature, relative humidity and changes in precipitation, land surface temperatures and vegetation created and facilitated conditions for transmission of diseases, resulting in an uptick in reported cases that influenced the spread of infectious diseases.[7]

In their treatise "Navigating the Structure of Research on Sustainable Development Goals," Nakamura, et al. [8] found that there as many sustainable development goal (SDG)-related health and healthcare researches, as are studies on the environment and agricultural aspects of sustainability.

Of the 17 United Nations SDGs, [9] climate change is the most pressing challenge the world fac- es today. It affects all aspects of the development agenda, from poverty eradication to food security to health care, and from economic growth to disaster risk reduction.

Social inequities exist globally, and we see how the poorest and most vulnerable people are likely to be most affected by climate change. Adam Smith wrote in his book "The Theory of Moral Sentiments," and I quote: "...there is something in us that requires us to see the happiness in others even if we do not derive any profit from it, except the joy of seeing it," [10] hence we should exert significant efforts to create models of development that can mitigate climate change and allow the marginalized to adapt to its impact.

At the 2016 World Medical Association Convention in Moscow, Russia, I met and spoke with the then World Medical Association (WMA) President Sir Michael Marmot of the University College, London. He is a staunch advocate for research involving the social determinants of health and authored the books "The Health Gap: The Challenge of an Unequal World" [1 1] and "The Status Syndrome: How Social Standing Affects Our Health and Longevity."[12] As a physician, he believes that we contribute to social injustice and alienation whenever we treat patients by giving them medicines but do nothing to alleviate their social status and environmental conditions.

This brings to mind the rectorial address of Jimmy Reid delivered in the University of Glasgow on April 28,1972 . He defined alienation as "...the cry of men who feel themselves the victims of blind economic forces beyond their control...the frustration of ordinary people excluded from the processes of decision-making...the feeling of despair and hopelessness that pervades people who feel with justification that they have no real say in shaping or determining their destinies."[13]

Indeed, there exists a climate change-social inequality vicious cycle whereby disadvantaged groups suffer greater exposure and vulnerability to climate change causing excessive loss of assets and income resulting in greater subsequent inequity.[14] The terms inequality and inequity differ, in that the former is simply a dimensional description employed whenever quantities are unequal, while the latter requires passing a moral judgment that the disparity is wrong and we must do something to remedy the situation. So in 2018, I wrote and published "The Social and Cultural Dimensions of Health as a Research Agen- 
da: Establishing the Need for a Research Interest Group (RIG) in Social Medicine." as a wake-up call. [15] Doing research is not just about publishing for career advancement but for promoting social good.

As researchers, we are involved in the generation of knowledge, and we are personally implicated in the way it will be used. Kurt Lewin once said: "There is no research without action, no action without research."[16]

The role of research and innovation in addressing social determinants of health and promoting health equity has been emphasized by the WHO's Commission on Social Determinants of Health, which in 2008 published the report "Closing the gap in a generation: Health equity through action on the social determinants of health": "It is through the democratic processes of civil society participation and public policy-making, supported at the regional and global levels, backed by the research on what works for health equity, and with the collaboration of private actors, that real action for health equity is possible".[17]

At the Global Health Forum in 2015, Carel lisselmuiden, Executive Director of the Council for Health Research and Development (COHRED) [18] exhorted all researchers to shift their focus from "health research and innovation" to "research and innovations for health," a play of words that changes the whole meaning and purpose of why we should be doing research.

Like all physicians, I swore my allegiance to the Hippocratic Oath to "First do no harm." As an anesthesiologist, I am proud to follow the long tradition of peers who swore to treat the sick and protect them from injustice. In recent years, medicine has evolved in unimaginable ways. We are specialists who are experts at healing our patients. As a clinical epidemiologist, however, my curious mind asks the questions: How come diseases are still growing in epidemic proportions? What makes people sick?

Then we start looking from another vantage point, and we see that the healthcare sector impacts on climate change. As large consumers of energy and water, health care activities have a significant climate impact. Health facilities have been estimated to contribute between $3-8 \%$ of national greenhouse gas emissions in developed countries.[19]

The burning of fossil fuels associated with heat and power production, procurement, transportation, etc. all leave carbon footprints. In the entire produc- tion and disposal lifecycle, the acquisition of medical equipment and materials, food, medicines and other consumable goods is the health sector element with the largest carbon footprint.

Climate emission of health sector activities includes carbon dioxide, a major long-lived pollutant which persists for centuries, as well as, many short-lived climate pollutants (SLCPs). Although they remain for less time in the atmosphere than CO2, SLCPs nevertheless have more powerful warming impact for the time that they are present.

Low-income countries use black carbon as the primary energy source in kerosene lamps, waste incineration and transportation. Health facilities also use it for power production in facility diesel backup generators or coal power sources. Moreover, it is a significant component of health harmful-particulate matter and major air pollutants that have a significant respiratory impact.

Coal fossil fuel used to provide power for health facilities release methane. As a by-product emission of sewage and solid healthcare waste, it also contributes to ground-level ozone formation.

Refrigerators and cooling equipment leak hydrofluorocarbons into the atmosphere when they are damaged.

In a 20 -year time frame, the widely used inhaled anesthetic gas nitrous oxide and the halogenated hydrofluorocarbon anesthetic vapors such as isoflurane, desflurane and sevoflurane have global warming potentials hundreds or thousands of times higher than $\mathrm{CO} 2$. It was estimated that the annual global climate impact of anesthetic agents was equivalent to the $\mathrm{CO} 2$ emissions from one million cars.[20]

We have read stories of plunder, destruction and devastation due to logging and mining activities that have stripped our land of natural resources resulting in heavy metal poisoning of our rivers through spilled mining tailings of copper and lead in Mogpog and Boac rivers in Marinduque; mercury poisoning of rivers in Mt. Diwalwal due to gold mining and panning.[21] Moreover, we see how medical wastes are finding their way into our waterways;[22] we see our esteros dumped with garbage and human wastes clogging the tributaries and pushing the wastes upstream to Pasig river.[23] Water pollution is one of the biggest problems affecting the Philippines. According to the Department of Environment and Natural Resources (DENR), as many as 180 of the 421 rivers in the country and other bodies of wa- 
ter nationwide are so heavily polluted that they may soon be declared "biologically dead."[24] Biologically dead rivers no longer contain any oxygen and cannot support any but the hardiest kinds of species.

Realizing all these, I speak at various fora here and abroad regarding the need to address climate change to preserve health and ensure food security.

All these things happening around us begs the questions: "So what causes wellness and health?" "What is it that makes us well?" "How do we empower our people to seek health instead of degenerating into ill-health?"

We have all heard about the Circle of Life, but how about the River of Life? Traditionally, society has viewed health as the absence of sickness, hence pathogenesis. In medicine, we focus our subjects in the study of diseases or more specifically, the study of the cause of bad health.

In 1979, the medical sociologist Aaron Antonovsky in "Health, Stress and Coping" introduced the term "salutogenesis" or the salutogenic concept of health, also known as the "River of Life." Salutogenesis is derived from Salus, the Roman Goddess of welfare and safety. Salutogenesis takes on the opposite view. It is the study of ease, of the cause of good health, in particular, the factors contributing to the quality of life, health and well-being.[25]

As physicians, we trained in the pathogenic or disease-focused way of thinking - about how to diagnose disease, treat and prevent disease. Pathogenesis focuses on a high risk or a risk reduction with shifting of high-risk individuals to the normal range. Salutogenesis, on the other hand, focuses on the low-risk population to bring people to a state of ease or well-being. This phenomenon is known as the bell-curve shift in populations.

He raised the question of why some people, regardless of major stressful situations and severe hardships, flourish and stay healthy while others do not. $\mathrm{He}$ introduced the salutogenic concept of a "sense of coherence." He claimed that people become healthy when they view life as comprehensible, manageable and meaningful. A strong sense of coherence helps one mobilize resources to cope with stressors and manage tension and move successfully in the health ease/dis-ease continuum.

Meaning and purpose are at the core of this concept. People with purpose are known to be more resilient because they can find meaning and learning in all of life's experiences - the good and the bad.
While some people get knocked down and stay rock bottom, resilient people bounce back from their misfortune with a smile on their face and a spring in their step.

Personal and planetary health is fundamentally interconnected! The root causes of ill health in individuals' parallels the root causes of converging crises that are affecting our ailing planet. Both phenomena run deep into how we approach our health and wellbeing, as much as how we approach the environment through our culturally dominant worldview and value system. In "The Roots of Health," Fraser and Hill wrote "...we cannot sustain health without addressing what is needed throughout the interconnected systems of our lives, ourselves as individuals, our physical health, our psychological health, our relationships with our families, our communities and our environment. In regaining the roots of our health, we may learn to be better stewards of the earth as well as of ourselves."[26]

Dear colleagues, while we are young we sometimes go with the flow...but as we grow older, we realize that we can, and we must change the flow. Change can be scary. But we must never forget that change can also be good. Today, we stand at crossroads in the history of health care in this great nation. Behind us lies a century of failed attempts to improve the system. Ahead of us lie two distinct paths.

One is the path of inaction - of glorifying the past, succumbing to partisan politics that muddle all our issues and thwarting any attempt to move forward. The other is the path of action-of collaborating, innovating and leading the drive toward productive change. We, at the University of Santo Tomas train future leaders who will continue to nurture and develop our society into a vibrant future. We can truly call ourselves leaders, and I am honored and proud to be among fellow leaders who think creatively, work collectively and lead passionately! We all look forward to many more years of learning, sharing, mentorship and forming lasting friendships. Here I aptly quote Mahatma Gandhi when he said, "The best way to find yourself is to lose yourself in the service of others," and "Be the change you want to see in the world."[27]

There are three types of people in the world according to Steve Backley: 1. Those who make things happen; 2 . Those who watch while things happen; and 3. Those who do not know what is happening and ask what happened.[28] 
Colleagues, I know that the University of Santo Tomas is composed of academicians and researchers determined to make things happen and I look forward to walking that path of action with fellow Thomasian mentor-researcher leaders in the years ahead. We are doing right by our students and mentees, and we are leveraging the power of the Thomasian spirit to mold the minds of future leaders in our country-its future is in our hands.

I remember our mother exhorting us that we should always utter a prayer of gratitude to God for our successes. That if ever we should find ourselves in any position of power or influence, that we should have it in us to use it to make only good choices. Let me paraphrase Jimmy Reid again when he cautioned: "Reject the insidious pressures in society that would blunt your critical faculties to all that is happening around you, that would caution silence in the face of injustice afraid that we might jeopardize your chances of promotion and self-advancement."[13]

Let us not be afraid to speak up on social issues. Be wary however that there is such a thing as a Strategic Lawsuit Against Public Participation (SLAPP), a lawsuit that is intended to censor, intimidate and silence critics by burdening them with the cost of a legal defense until they abandon their criticism or opposition. [29] Such lawsuits have been made illegal in many jurisdictions because they impede freedom of speech.

In 1853, a collection of "Ten Sermons of Religion" by Theodore Parker was published and the third sermon entitled "Of Justice and the Conscience" included figurative language about the arc of the moral universe which Martin Luther King Jr. paraphrased thus, "Let us realize the arc of the moral universe is long, but it bends toward justice." Parker in his original sermon alluded that it is only through our own conscience, and thereby our own actions, that justice will be achieved.[30]

As a Thomasian community, we are action researchers. Let us do researches that promote salutogenesis and address the social determinants of health; let us encourage inclusivity and reject any form of alienation. Let us do studies that create opportunities to promote healthy behaviors and safety. Let us design cities to promote physical activity, improve road safety, make healthy food available and affordable, and provide health services for all. Let us encourage public participation through dialogue and involve communities in decision-making. Let us build inclusive cities that are accessible and age-friendly and make living spaces resilient to emergencies and disasters.

The Filipinos are not poor. We cannot be poor if there is true love and genuine generosity. Let us give our time, talent and treasure! If you do not have treasures give time and talent! If you do not have treasures and time, give your talent! Let us end the culture of alienation and let the River of Life flow in all of us.

Many of us go on missions giving off our time and talent and we receive immeasurable love in return. And from an unknown author, allow me to quote: "At the end of life, what really matters is not what we bought, but what we built; not what we got, but what we shared; not our competence, but our character; and not our success, but our significance. Live a life that matters. Live a life of love".[31] Instead of tangible things passed on as inheritance, let us instead think of the legacy that we want to leave behind, individually and collectively.

Allow me to end with a quote from a fellow physician, very Rev. Father Bruno Cadoré, O.P., the 87th Master of the Order of Preachers and Chancellor of the University, during the mass at the UST Hospital blessing last July 4, 2019:

"Not only to care and cure but to help patients bring back their confidence to themselves so they can regain their value and function as human beings. Education and research based on compassion. The Hospital in the university is like a sacrament-God's love, God's compassion for humanity. To make the university a community, let us ask God to make us ambassadors of compassion in this world through Christ today and forever."[32]

We celebrate Our Legacy: A Distinguished Past, A Vibrant Future! 


\section{REFERENCES}

1. Pe JL. The University of Santo Tomas in the twentieth century. University of Santo Tomas Press; 1973.

2. De Ramos NV. I walked with twelve UST rectors. Quezon City: A.G. Ablaza and C. de Ramos Ablaza; 2000.

3. Martin Luther King Jr. I have a dream: Writings and speeches that changed the world. James Melvin Washington, editor. HarperOne; 2003.

4. Papa Francisco. Laudato Si: sobrecuidado de la casa común [Internet]. 2015.

5. Gore Al. An inconvenient truth: The planetary emergency of global warming and what we can do about it. Rodale. 2006.

6. Ocampo Country report on climate change policies, green jobs and decent work in the Philippines. 2015.

7. Stockdale T, Balmaseda M, Ferranti L. 2015-2016 El Niño and beyond. Newsletter. 2017.

8. Nakamura M, Pendlebury D, Schnell J, Szomszor M. Navigating the structure of research on sustainable development goals. Policy. 2019 Apr.

9. Programme UND. Sustainable development goals. [cited 2019 Jun 26]. Available at: https://www.undp.org/content/undp/en/home/sustainable-development-goals.html

10. Smith A. The theory of moral sentiments. 2011;161-2.

11. Marmot $M$. The health gap: The challenge of an unequal world. Bloomsbury Publishing; 2015.

12. Marmot M. The status syndrome: How social standing affects our health and longevity. Times Books; 1 Apr 2007.

13. Reid J. Alienation [Internet]. 1972. Available at: https:// www.gla.ac.uk/media/Media_167194_smxx.pdf

14. Islam SN and Winkel J. Climate change and social inequality. United Nations Department of Economics and Social Affairs. 2017.

15. Calimag MMP. The social and cultural dimensions of health as a research agenda: establishing the need for a Research Interest Group (RIG) in social medicine. Journal of Medicine University of Santo Tomas. 2008; 1 (1):1-4.

16. Adelman C. Kurt Lewin and the origins of action research. Educational Action Research. 1993 Jan 1;1(1):7-24.

17. Closing the gap in a generation: Health equity through action on the social determinants of health. 2008. Geneva, Switzerland: World Health Organization, Commission on Social Determinants of Health.

18. Carel lisselmuiden. Executive Director of the Council for Health Research and Development (COHRED) Speech during the global health forum in Manila, Philippines. 2015.

19. Eckelman M, Sherman J. Environmental impacts of the US health care system and effects on public health. PloS one. 2016 Jun 9;11(6):e0157014.

20. Sulbaek Andersen MP, Sander SP, Nielsen OJ, Wagner DS, Sanford Jr TJ, Wallington TJ. Inhalation anaesthetics and climate change. British Journal of Anaesthesia. 2010 Dec $1 ; 105(6): 760-6$

21. Dizon N. The Marcopper disaster: A tragedy that continues in people's veins. 3 April 2019.

22. Erram, M., 2019. Lapu-Lapu Cenro Retrieves Sacks Of Floating Hospital Wastes From Mactan Channel. [Internet] [cited 2019 Jun 26] Available at: https:// www.google.com.ph/amp/s/cebudailynews.inquirer.net/2 11805 /sacks-of-hospital-wastes-hauled-offmactan-channel-as-lapu-lapu-cenro-starts-sea-patrol/ amp

23. Añonuevo-Arcega M. Pasig River is world's 2 nd biggest source of plastic waste for its size-study. 13 June 2017.

24. Bengwayan, M., 2019. Many Philippine Rivers Are Dying Oped. [Internet] Eurasia Review - News and Analysis. [cited 2019 Jun 26]. Available at: https://www.eurasiareview. com/29042019-many-philippine-rivers-are-dying-oped.

25. Antonovsky A. Health, stress and coping. Jossey-Bass; 1979.

26. Fraser R and Hill S. The roots of health: Realizing the potential of complementary medicine. Green Books for the Schumacher Society; 2001.

27. Ashoka. 12 great quotes from Gandhi on his birthday. 2 Oct 2012.

28. Backley S. The champion in all of us: 12 rules for success. Mirage Publishing; 2013.

29. Pring GW. SLAPPs: Strategic lawsuits against public participation; 1989

30. Smith MD. The truth about "The Arc of the Moral Universe" Jan 4, 2018.

31. Tiny Buddha: Simple wisdom for complex lives [Internet]. [cited 2019 Jun 28] Available at: https://tinybuddha. $\mathrm{com} /$ wisdom-quotes/end-life-really-matters-not-bought-builtnot-got-shared-not-competence-character-not-success-significance/

32. Cadoré B. Speech delivered during the mass at the UST Hospital blessing. July 4, 2019.

(i) Open Access This article is licensed under a Creative Commons Attribution 4.0 International License, which permits use, sharing, adaptation, distribution and reproduction in any medium or format, as long as you give appropriate credit to the original author(s) and the source, provide a link to the Creative Commons license, and indicate if changes were made. The images or other third party material in this article are included in the article's Creative Commons license, unless indicated otherwise in a credit line to the material. If material is not included in the article's Creative Commons license and your intended use is not permitted by statutory regulation or exceeds the permitted use, you will need to obtain permission directly from the copyright holder. To view a copy of this license, visit http://creativecommons.org/licenses/by/4.0/. 